\title{
CORN RESPONSE TO TWO FERTILIZATION RATES UNDER SW SPAIN CONDITIONS
}

\author{
J. M. Murillo, F. Moreno, F. Cabrera, and C. Castro
}

Instituto de Recursos Naturales y Agrobiologfia de Sevilla. Apartado 1052. 41080, Sevilla, Spain

ABSTRACT: Corn cv. PRISMA response (growth, plant composition, and yield) was studied in relation to two fertilizer treatments: the high rate used in irrigated fields in SW Spain (1000 kg/ha 15-15-15 fertilizer plus two applications of $400 \mathrm{~kg}$ urea $(46 \% \mathrm{~N}) / \mathrm{ha})$; and the same reduced to one-third. Plant height ( $290 \mathrm{~cm})$, specific leaf area $\left(0.018 \mathrm{~m}^{2} / \mathrm{g}\right)$, ear weight $(\sim 210 \mathrm{~g})$, kernel weight per ear ( $185 \mathrm{~g})$, and estimated yield $(\sim 16 \mathrm{Mg}$ /ha) were similar with both treatments. Plant nutrient contents were similar in the leaf level, with both treatments, although the $N$ content of stalk and kemel (at harvest) were higher $(P<0.05)$ when the high fertilization dose was applied. DRIS indices presented $\mathrm{N}$ and $\mathrm{S}$ as the more balanced nutrients, and in general the $\mathrm{P}$ and $\mathrm{Mg}$ contents were comparatively low, and $\mathrm{Ca}$ and $\mathrm{K}$ comparatively high. Amounts of $\mathrm{N}$ and $\mathrm{P}$ removed by corn (above-ground part) were higher than those fertilized at the lower rate. Removed $\mathrm{K}$ was considerably higher than the loaded amount, whichever rate of fertilization was considered. When fertilized with a comparatively low rate (for irrigated regimes in SW Spain), the natural reserves of the previously fertilized sandy loam soil used in the assay contributed to achieve a high yield with a high-yielding corn crop.

\section{INTRODUCTION}

It is well known that many conventional fertilization systems apply higher amounts of nutrients than plants require. As was pointed out by Olson et al (1), these philosophies of fertilization are frequently oriented towards fertilizing the 
TABLE 1. Soil Description (Mean Values).

\begin{tabular}{|c|c|c|c|}
\hline \multirow[b]{2}{*}{ PARAMETER } & \multicolumn{3}{|c|}{ DEPTH $(\mathrm{cm})$} \\
\hline & & $0-50$ & $50-100$ \\
\hline Sand & $(\%)$ & 78 & 75 \\
\hline Silt & $(\%)$ & 9 & 8 \\
\hline Clay & $(\%)$ & 13.5 & 16 \\
\hline $\mathrm{CaCO}_{3}$ & $(\%)$ & 5.2 & 3.1 \\
\hline $\mathrm{pH}\left(\mathrm{H}_{2} \mathrm{O}\right)$ & & 7.2 & 7.1 \\
\hline O.M. & $(\%)$ & 0.9 & 0.6 \\
\hline N-Rjeldha 1 & (pp2m) & 1197 & 908 \\
\hline Puolsen & (pp2m) & 24 & 18 \\
\hline R-available" & (pp2m) & 414 & 346 \\
\hline
\end{tabular}

Extraction with amonium acetate.

soil more than the crop, which can imply a potential environmental risk (groundwater pollution).

However, various authors do not agree with limiting fertilizer applications just to cover plant requirements. Farina (2) cited "the astonishingly low levels of fertilizers many farmers are currently being persuaded to use". As a contribution to this controversial topic, a comparative study of the effect of a high, but conventional fertilization of corn in SW Andalusia (3), and the same treatment but reduced to one-third, has been initiated. This paper deals with the crop results obtained in the first year. Results of nutrients and water dynamics in the soil will be considered in another publication.

\section{MATERIALS AND METHODS}

The study was carried out in an $800 \mathrm{~m}^{2}$ plot (Coria del Rio, Seville). The soil (a sandy loam) is a XEROCHREPT (4), whose physical and chemical spatial 
TABLE 2. Fertilization (kg/ha) of Previous Crops.

\begin{tabular}{lcccc} 
YEAR & CROP & N & P & K \\
\hline 1987 & Spring-Sumer: Sunflower & 45 & 25 & 38 \\
1988 & Winter-Spring: Barley & 90 & 25 & 38 \\
1989 & Spring-Summer: Melon & 170 & 50 & 92 \\
1990 & Hinter-Spring: Potato & 150 & 42 & 63 \\
\hline
\end{tabular}

variability within the plot was initially studied by the "Kriging" method (5). Table 1 shows the mean values of soil variables analysed. Corn (Zea mays $L$. cv. PRISMA (G-4730), cycle: $800\left(2176^{\circ}-2225^{\circ}\right)$ was sown on April 5, 1991. The plant population was 75,000 standing plants/ha. Irrigation, in the range of $30-50$ $\mathrm{mm}$ per day, was applied when needed depending on climatic conditions and plant development. The irrigation water (that normally used in this zone), contained high levels of NO3-N ( 0.7 meq/L) and $\mathrm{Cl}(\sim 10 \mathrm{meq} / \mathrm{L})$. Plaguicide, insecticide, and fungicide were also applied when necessary. The previous crops and fertilization of the plot are shown in Table 2.

The plot was divided into two sub-plots $\left(400 \mathrm{~m}^{2}\right)$, one was fertilized with a conventional rate (1000 kg/ha) of a complete fertilizer [15\% N, 8\% P (15\% P2O5) and $15 \% \mathrm{~K}$ ] before sowing, and two applications of $400 \mathrm{~kg} / \mathrm{ha}$ of urea 50 and 60 days after sowing. In the other sub-plot, this fertilization was reduced to onethird, sufficient to cover the $\mathrm{P}$ and $\mathrm{K}$ requirements of the crop according to the reported corn nutrient extraction and potential soil supply in Spanish conditions 
(6). These two treatments will be identified as $\mathrm{F}$ and $1 / 3 \mathrm{~F}$ throughout the paper, respectively.

Plant material was collected at the following days after sowing: 24 days (above-ground part, $\sim 14 \mathrm{~cm}$ height), 45 days (leaves, data not shown in this paper), 75 days (3th upper leaf; $\sim 140-150 \mathrm{~cm}$ height-early tasseling), and 104 days (leaf below ear; $\sim 290 \mathrm{~cm}$ height). The latter were used to obtain leaf area by a SKYE leaf areameter. Specific leaf area (SLA) was obtained by division of the leaf area by the corresponding dry leaf weight. To estimate yield, five representative points were selected in each sub-plot 140 days after sowing, and ears from 16 plants around each point (80 ears per sub-plot) were weighed and thrashed at a kernel moisture of $10 \%$ (7). The weight of a thousand kernels was also measured per subplot. Yield was also measured in the field. To estimate the above-ground nutrient removal, six plants per sub-plot were taken 140 days after sowing, weighed, and the plants divided into leaves, stalks, and ears, and analysed.

Above ground parts (leaves, stalks, rachies, and kernels) were dried at $70^{\circ} \mathrm{C}$, after decontamination by washing, and ground. Nitrogen was determined by Kjeldahl digestion, and $S$ by the magnesium nitrate method (8), with turbidimetric determination of sulfate as $\mathrm{BaSO}_{4}$ (9). Mineral elements were determined according to Jones et al. (10) following dry ashing and ash solution by treatment with $\mathrm{HCl}$ on a hot plate. Sodium and $\mathrm{K}$ were determined by flame emission, and $\mathrm{Ca}$ and $\mathrm{Mg}$ by atomic absorption spectrometry, $\mathrm{P}$ by colorimetric determination using the phosphovanadomolybdic complex. DRIS indices were calculated according to norms proposed by Elwali et al. (11) for corn. The Student's test was used to test differences in paired means.

\section{RESULTS AND DISCUSSION}

Plant Growth and Production: Some parameters related with plant growth and production are shown in Tables 3 and 4. It can be seen in Table 3 that the height and leafiness of the plants were not affected by fertilization level. On the other hand, Table 4 shows that yield, and some other parameters related with production, are not either affected by the fertilization level, although curiously, values of treatment $1 / 3 F$ tended to be a little higher than those of the treatment $F$, their difference being statistically significant only for 1000 kernel weight. 
TABLE 3. Mean Values of Plant Height, Leaf Area, Leaf Weight and Specific Leaf Area.

\begin{tabular}{lcccc}
\hline TREATMENT & $\begin{array}{c}\text { PLANT HEIGHT } \\
(\mathrm{cm})\end{array}$ & $\begin{array}{c}\text { LEAF AREA } \\
\left(\mathrm{m}^{2}\right)\end{array}$ & $\begin{array}{c}\text { LEAF WEIGHT } \\
(\mathrm{g})\end{array}$ & $\begin{array}{c}\text { SPE. LEAF AREA } \\
\left(\mathrm{g} / \mathrm{m}^{2}\right)\end{array}$ \\
\hline & & & & \\
F & & & & \\
F $1 / 3$ & & $0.08 \mathrm{a}$ & $4.45 \mathrm{a}$ & $0.018 \mathrm{a}$. \\
& $294 \mathrm{a}$ & $0.08 \mathrm{a}$ & $4.36 \mathrm{a}$ & $0.018 \mathrm{a}$ \\
\hline
\end{tabular}

Values followed by the same letter in the same column do not differ significantly $(P<0.05)$.

As shown in Table 4, estimated yield (from 80 ears per subplot) is higher than that obtained in the total plot. It can be assumed that the current kernel losses at field level, and the corresponding error, are totally minimized at laboratory level. It is important to note that yields are expressed in terms of $\mathrm{Mg} / \mathrm{ha}$. On the other hand, yields of $\sim 14-15 \mathrm{Mg} /$ ha are normal for the corn cv. PRISMA cultivated in productive soils of Andalusia (3).

Plant Nutrients: The concentration of macronutrients, and $\mathrm{Na}$, for corn at several stages of growth are shown in Table 5. Sufficiency ranges and critical levels for the same nutrients are also given.

Twenty-four days after sowing, the $P$ content of the plants $(14 \mathrm{~cm}$ height) was below the sufficiency range proposed for this period (Table 5). Calcium content, on the other hand, was higher than the corresponding sufficiency range, while $\mathrm{N}$, $\mathrm{K}, \mathrm{S}$, and $\mathrm{Mg}$ contents were within the limits of their respective sufficiency ranges. DRIS indices (Table 6) corroborate this diagnosis, $\mathrm{P}$ and $\mathrm{Ca}$ being, theoretically, the most unbalanced nutrients, deficient and in excess, respectively. 
TABLE 4. Hean Values of Ear Weight ( $g$ ), Kernel Weight per Ear ( $g$ ), 1000 Rernel Weight (g) and Yield (Mg/ha).

\begin{tabular}{|c|c|c|c|c|c|}
\hline TREAT & EAR & RERNEL WEIGHT & 1000 KERNEL & \multicolumn{2}{|c|}{ YIELD } \\
\hline MENT & WEIGHT & PER EAR & HEIGHT & $1^{*}$ & 2 \\
\hline F & $208.6 a$ & $181.0 \mathrm{a}$ & $313.7 \mathrm{~b}$ & $15.6 \mathrm{a}$ & $13.0 \mathrm{a}$ \\
\hline F $1 / 3$ & $214.1 \mathrm{a}$ & $188.3 \mathrm{a}$ & $334.4 a$ & $16.1 \mathrm{a}$ & $13.2 \mathrm{a}$ \\
\hline
\end{tabular}

* 1: Estimated from 80 ears per sub-plot.

2: Obtained in the total sub-plot.

Values followed by the same letter in the same column do not differ significantly $(P<0.05)$.

Seventy-five days after sowing, the corn plants were at the initial tasseling stage. Phosphorus appears now as the element in proper balance according to both the critical level proposed by Melsted et al. (12) (Table 5) as well as by the DRIS criteria (Table 6). This coincides with the lowering of $\mathrm{Ca}$ levels in plants (Table 5). At this period, the DRIS values for $\mathrm{Mg}$ and $\mathrm{K}$ appear as the most unbalanced nutrients, deficient and in excess, respectively (Table 6).

At 104 days after sowing, corn plants had completed the silk stage. The $\mathrm{Ca}$ and $\mathrm{K}$ contents of the plants (leaf below ear) are close to the upper limits of the sufficiency ranges proposed by Jones and Eck (13) for both nutrients at the silking stage (Table 5). Both are, according to the DRIS theory, the most unbalanced nutrients by being in excess (Table 6). Phosphorus is again the most unbalanced nutrient and $\mathrm{S}$ the most balanced (Table 6). Nitrogen and $\mathrm{Mg}$ show an opposite pattern with the fertilization level, with $\mathrm{N}$ being about adequate to satisfy the com requirement according to the proposed sufficiency level value (Table 5).

Except for initial tasseling, $\mathrm{P}$ and $\mathrm{Mg}$ were deficient, and $\mathrm{K}$ and $\mathrm{Ca}$ in excess, therefore being theoretically the most unbalanced nutrients, while $S$ and $N$ are the 
TABLE 5. Analysis of Corn. Mean Values (\%) on a Dry Mater Basis.

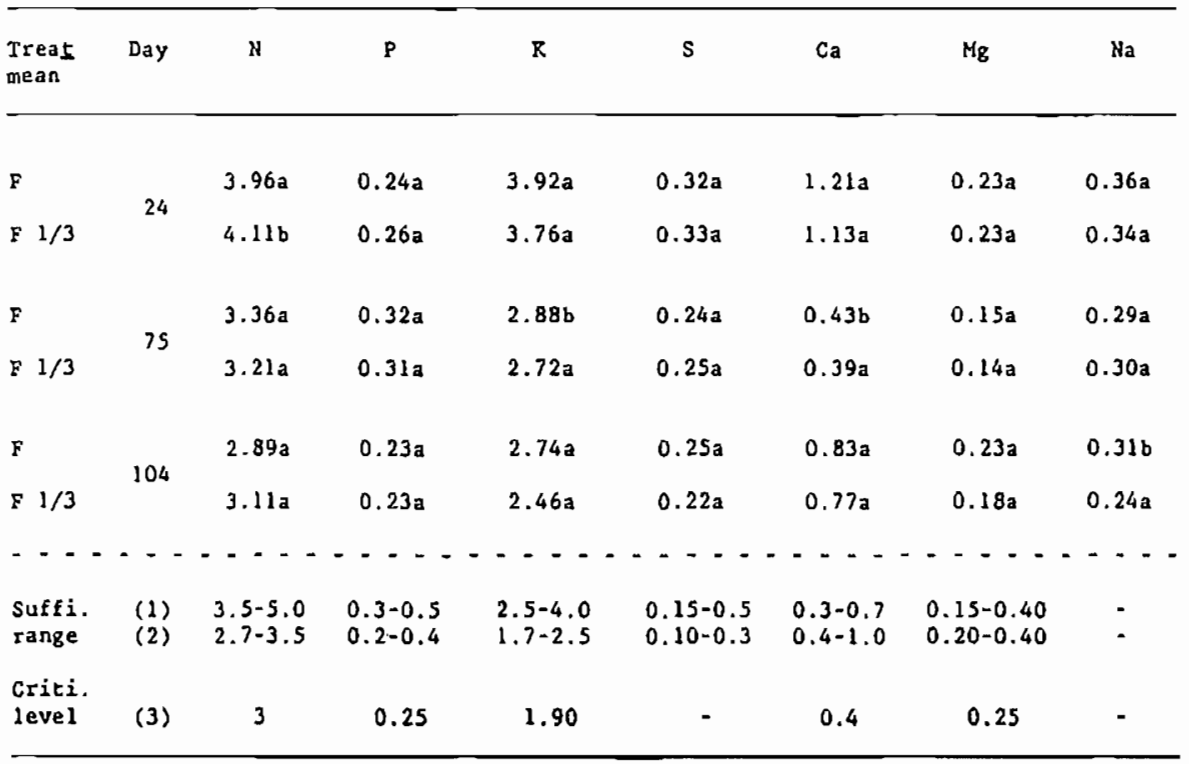

(1) According to Benton Jones, $\mathrm{Jr}$. et al (10): whole top; plants $<30 \mathrm{~cm}$.

(2) According to Benton Jones, Jr. and Eck (13): ear leaf; silk stage.

(3) According to Melsted et al (12): leaf at, or opposite and below, ear level at tassel stage.

Pairs of values followed by the same letter in the same colum do not differ significantly $(P<0.05)$.

most balanced. However, it is important to note that the DRIS norms proposed by Elwali et al. (11) have not been tested for SW Spain conditions. Thus, it is possible that under these conditions, DRIS norms identified by Elwali et al. (11) for high yields of corn would be different than those determined in our study. There are no sufficiency range and norms for $\mathrm{Na}$, although the levels reached by corn seem to be clearly higher than those needed, if so, for physiological purposes.

Our results, based on the analysis of the above ground parts (young plants, day 24) and leaf levels (days 75 and 104), show that fertilization rate is not 
TABLE 6. DRIS Indices and Order of Requirement by DRIS of Corn.

\section{DRIS INDICES}

\begin{tabular}{|c|c|c|c|c|c|c|c|c|}
\hline TREATMENT & DAY & N & $\mathbf{P}$ & $\mathbf{K}$ & $\mathrm{Ca}$ & $\mathrm{Mg}$ & $\mathbf{s}$ & REQUIREMENT DRIS \\
\hline \multirow[t]{2}{*}{$\mathbf{F}$} & & -0.5 & -36.4 & 18.4 & 29.0 & -8.9 & -1.6 & $\mathrm{P}>\mathrm{Mg}>\mathrm{S}>\mathrm{N}>\mathrm{K}>\mathrm{Ca}$ \\
\hline & 24 & & & & & & & \\
\hline F $1 / 3$ & & 1.7 & -31.6 & 14.8 & 24.4 & -9.3 & -0.02 & $\mathrm{P}>\mathrm{Mg}>\mathrm{S}>\mathrm{N}>\mathrm{K}>\mathrm{Ca}$ \\
\hline \multirow[t]{2}{*}{ F } & & 4.8 & -2.8 & 13.8 & -7.2 & -10.2 & 1.6 & $\mathrm{Mg}>\mathrm{Ca}>\mathrm{P}>\mathrm{S}>\mathrm{N}>\mathrm{K}$ \\
\hline & 75 & & & & & & & \\
\hline F $1 / 3$ & & 6.2 & -3.0 & 11.4 & -5.0 & -12.9 & 1.3 & $\mathrm{Mg}>\mathrm{Ca}>\mathrm{P}>\mathrm{S}>\mathrm{N}>\mathrm{K}$ \\
\hline \multirow[t]{2}{*}{ F } & & -4.9 & -23.3 & 11.2 & 19.4 & -0.01 & -2.4 & $\mathrm{P}>\mathrm{N}>\mathrm{S}>\mathrm{Mg}>\mathrm{K}>\mathrm{Ca}$ \\
\hline & 104 & & & & & & & \\
\hline $\mathbf{F}$ & & 2.8 & -19.0 & 8.4 & 19.0 & -7.6 & -3.6 & $\mathrm{P}>\mathrm{Mg}>\mathrm{S}>\mathrm{N}>\mathrm{K}>\mathrm{Ca}$ \\
\hline
\end{tabular}


TABLE 7. Corn Analysis at Harvest. Mean Values (\%) on a Dry Matter Basis.

\begin{tabular}{|c|c|c|c|c|c|c|c|c|}
\hline $\begin{array}{l}\text { PLANT } \\
\text { PART }\end{array}$ & TREATMENT & N & $\mathbf{P}$ & K & $\mathbf{s}$ & $\mathrm{Ca}$ & $\mathrm{Mg}$ & $\mathrm{Na}$ \\
\hline & $\mathbf{F}$ & $1.14 a$ & $0.10 a$ & $2.40 \mathrm{a}$ & $0.18 a$ & $1.10 \mathrm{a}$ & $0.17 a$ & $0.24 a$ \\
\hline \multicolumn{9}{|c|}{ LEAF } \\
\hline & $\mathrm{F} 1 / 3$ & $1.16 a$ & $0.10 \mathrm{a}$ & $2.15 a$ & $0.17 a$ & $1.17 \mathrm{a}$ & $0.17 a$ & $0.17 a$ \\
\hline & $\mathbf{F}$ & $0.90 a$ & $0.05 a$ & $4.10 a$ & $0.05 a$ & $0.66 a$ & $0.18 a$ & $0.32 a$ \\
\hline \multicolumn{9}{|c|}{ STALR } \\
\hline & $\mathrm{F} 1 / 3$ & 0.476 & $0.03 \mathrm{a}$ & $4.50 a$ & $0.07 a$ & $0.59 \mathrm{a}$ & $0.16 a$ & $0.32 a$ \\
\hline & F & $1.31 \mathrm{a}$ & $0.28 a$ & $0.34 \mathrm{a}$ & $0.09 \mathrm{a}$ & 0.066 & $0.44 a$ & $0.03 a$ \\
\hline \multicolumn{9}{|c|}{ KERNEL } \\
\hline & $F 1 / 3$ & $1.23 b$ & 0.266 & $0.32 b$ & $0.09 a$ & $0.07 a$ & $0.42 a$ & $0.03 a$ \\
\hline
\end{tabular}


TABLE 8. Amounts of Nutrient Applied in Both Treatments ( $F$ and $F 1 / 3$ ) and Removed by Corn, and Comparison with Estimates from the Literature $(\mathrm{kg} / \mathrm{ha})$.

\begin{tabular}{lcccccc}
\hline & \multicolumn{1}{c}{ FERTILIZATION* } & \multicolumn{4}{c}{ REMOVED } \\
NUTRIENT & F & F1/3 & F & F1/3 & 1 & 2 \\
& & & & & & \\
N & 570 & 230 & 260 & 240 & 260 & 300 \\
P & 80 & 27 & 65 & 53 & 46 & 60 \\
K & 163 & 63 & 300 & 300 & 172 & 230 \\
\hline
\end{tabular}

* Fertilization includes $60 \mathrm{~kg} / \mathrm{ha}$ of $\mathrm{N}$ and $13 \mathrm{~kg} / \mathrm{ha}$ of $\mathrm{K}$ applied with the irrigation water.

1: For a grain yield of $9.5 \mathrm{t} / \mathrm{ha}$ and $11.0 \mathrm{t} / \mathrm{ha}$ of straw: Mengel and Rirkby (15).

2: For a grain yield of $12 \mathrm{t} / \mathrm{ha}$ in $\mathrm{SW}$ Spain conditions: Guerrero (6).

significantly influencing the nutrient content of the corn plants. Statistical differences, when present, are irrelevant from a physiological point of view. However, when the more mature plant's (at harvest, day 139) leaves, stems, and kernels are analyzed, there are some differences in stem and kernel elemental levels (Table 7). There are similar concentrations of elements in the leaves. However, those plants receiving the complete, conventional fertilizer rate (F), possess higher contents of some elements in the stalk and kernels as compared to those plants receiving the reduced fertilizer treatment $(1 / 3 \mathrm{~F}$, Table 7$)$. In the case of $\mathrm{N}$ (stalk and kernel), and $\mathrm{P}$ and $\mathrm{K}$ (kernel), the differences are statistically 
significant $(\mathrm{P}<0.05)$. The difference in $\mathrm{P}$ content in the stalk is noticeable, despite the lack of significance between treatments (Table 7). The $\mathrm{Ca}$ and $\mathrm{Mg}$ contents of the kernels are also remarkable, being considerably higher than that reported by others (13).

Removed Nutrients: The plants receiving the higher fertilizer rate $(F)$ remove a little higher amount of $N$ and $P$ than plants receiving the lower (1/3F) rate (Table 8). But the most interesting feature is that total $N$ and $P$ amounts removed by the above-ground parts of the corn plant (analyses of ear rachies have been included) are lower than that applied in the complete, conventional fertilizer treatment (F). When that rate is reduced to one-third $(1 / 3 \mathrm{~F})$, the amount of nutrients applied barely meets the corn plant requirements for $N$ and $P$. Thus, the natural capacity of the soil to supply nutrients from its mineral/organic reserves (periodically provided by fertilization, Table 2), and the $\mathrm{N}$ applied with the irrigation water become very important.

In the case of $\mathrm{K}$, soil reserves have also contributed to plant uptake. The amounts removed are higher than those supplied in both sub-plots by fertilization ( $F$ and $1 / 3 F$, Table 7). On the other hand, estimated plant $K$ uptake in both sub-plots was higher than expected (Table 7). This may be due, at least in part, to the environmental conditions that exist in SW Spain, as the soil is well provided in $\mathrm{K}$ (Table 2) according to the Doll and Lucas (14) and Guerrero (6) criteria.

In a previously fertilized soil, a crop as exigent as corn reaches a high yield with a comparatively low fertilizer rate $(1 / 3 \mathrm{~F})$. Lowering of the $\mathrm{N}$-fertilization rate could diminish groundwater pollution, although the limitation must not be so drastic as to cause a parallel lowering in yield. First results have shown that at harvest, $\mathrm{NO} 3-\mathrm{N}$ in the first $30 \mathrm{~cm}$ of the soil of the sub-plot receiving the lower fertilizer rate was only about $10 \mathrm{mg} / \mathrm{kg}$. This value was about $30 \mathrm{mg} / \mathrm{kg}$ in the sub-plot receiving the higher fertilization rate.

The lower fertilizer rate $(1 / 3 \mathrm{~F})$ is perhaps somewhat limited for successive corn cultures (aspect under study), there being a neccessary gradual increase of this lower fertilizer rate. Optionally, a crop not so exigent as com could be selected in order to utilize the (periodically provided) natural reserves of the soil for a longer period of time, thus saving on the amount of fertilizer to be applied and diminishing the potential for groundwater pollution. 


\section{ACKNOWLEDGMENT}

Research carried out in the framework of the contract No. STEPCT90-0032-C (DSCN) of the CE.

\section{REFERENCES:}

1. Olson, R.A., F.N. Anderson, K.D. Frank, P.H. Grabouski, G.W. Rehm, and C.A. Shapiro. 1987. Soil testing interpretations: sufficiency vs. build-up and maintenance, pp 41-52. IN: J.R. Brown (ed.) Soil Testing: Sampling, Correlation, Calibration, and Interpretation. SSSA Special Publication No. 21. Soil Science Society of America, Inc., Madison, WI.

2. Farina, M.P.W. 1989. Economics of fertilizer use - Myths and facts. Fert. Soc. S. Afr. J. 1:17-24.

3. RAEA. 1989. Variedades de Maiz. Campania 87/88. Consejeria de Agricultura y Pesca de la Junta de Andalucia. Direccion General de Investigacion y Extension Agrarias. P.A.O., Suministros Graficos, Sevilla.

4. Soil Survey Staff, Soil Conservation Service, U.S. Department of Agriculture. 1975. Soil Taxonomy: A Basic System of Soil Classification for Making and Interpreting Soil Surveys. U.S. Dept. Agric. Handbook No. 436. U.S. Government Printing Office, Washington, D.C.

5. Moreno, F., B. Herrera, and J.M. Murillo. 1992. Spatial variability of some physical and chemical soil properties in an experimental plot. 1992 Conference of Working Group MV of the Int. Soc. of Soil Sci. , Ithaca NY (in press).

6. Guerrero, A. 1990. El Suelo, los Abonos y la Fertilizacion de los Cultivos. Ed. Mundi-Prensa, Madrid.

7. IBPGR. 1991. Descriptors for Maize. CIMMYT/IBPGR. IBPGR, Rome, Italy.

8. Horwitz, W (ed.) 1975. AOAC Official Methods of Analysis. Association of Official Analytical Chemists, Washington, D.C.

9. Bardsley, C.E., and J.D. Lancaster. 1965. Sulfur, pp 1102-1110. IN: C.A. Black (ed.) Methods of Soil Analysis, Part 2, Chemical and Microbiological Properties. Agronomy No. 9. American Society of Agronomy, Inc., Madison, WI.

10. Jones, Jr., J.B., B. Wolf, and H.A. Mills. 1991. Plant Analysis Handbook. Micro-Macro Publishing, Athens, GA.

11. Elwali, A.M.O., G.J. Gascho, and M.E. Sumner. 1985. Sufficiency levels and DRIS norms for 11 nutrients in corn. Agron. J. 77:506-508. 
12. Melsted, S.W., H.L. Motto, and T.R. Peck. 1969. Critical plant nutrient composition values useful in interpreting plant analysis data. Agron. J. $61: 17-20$.

13. Jones, Jr., J. B.and H.V. Eck. 1973. Plant analysis as an aid in fertilizing corn and grain sorghum, pp 349-364. IN: L.M. Walsh, and J.D. Beaton (eds.) Soil Testing and Plant Analysis. Soil Science Society of America, Inc., Madison, WI.

14. Doll, E.C. and R.E. Lucas. 1973. Testing soils for Potassium, Calcium, and Magnesium, pp 133-151. IN: L.M. Walsh and J.D. Beaton (eds.) Soil Testing and Plant Analysis. Soil Science Society of America, Inc., Madison, WI.

15. Mengel, K. and E.A. Kirkby. 1982. Principles of Plant Nutrition. International Potash Institute, Bern, Switzerland. 